\title{
ルアンプラバンの歴史的町並み保存に関する行政の取り組みと住民意識 CITIZEN CONSCIOUSNESS AND CONSERVATION POLICY FOR THE HISTORICAL PRESERVATION AREA OF LUANGPRABANG, Lao P.D.R
}

\author{
シッティワンソムチット*1, 河本順 子*2, 阿 部 浩 和*3 \\ Somchith SITTHIVAN, Junko KOMOTO and Hirokazu ABE
}

\begin{abstract}
In previous paper, the authors have examined about "Actual Situation of PSMV and Problem in Historic Conservation area in Luang Prabang Province, LAO P.D.R “. It reported that: Most of illegal buildings have non-permission, in this case had many of them violation on the material of wall, building form. And it was pending subject to survey the consciousness of citizen for preservation. In this paper aims to examine the Citizen's consciousness and Conservation policy, to find some of key for improving the Preservation plans of historic town of Luang Prabang through Citizen's Participation Approaching. The target subjects and area are the citizens, teachers, undergraduate students, administrators of government, Organization or the authorities concerned in Luang Prabang and Vientiane Lao,P.D.R. Some of results are as follows:
\end{abstract}

1) Citizen think that Luang Prabang is developing to become more beautiful, increasing of visitors after it was registered into the world heritage. But there are many of citizens think the regulation of preservation is being a problem to their housing construction.

2) By sharing the housing images has been performed that the houses which citizen regarded as seemingly LuangPrabang style should be preserved, but that is different type of houses so citizen prefers to live.

Keywords : Luang Prabang Lao.P.D.R, Historical Preservation Area,Citizen Consciousness, PSMV ラオス・ルアンプラバン、歴史的町並み保存、住民意識、PSMV

\section{1. 序}

ルアンプラバンはラオス人民民主共和国の古都で 1995 年にユネス コの世界遺産に登録されている。ラオス政府はユネスコの協力を得て 建築物や景観、自然環境の保存に関する規則P S MV (注1)を設け、そ の保全に取り組んできた(文1)。しかしその後の調査において、現状で はまだこのような規則が十分に守られていないという報告(文 ${ }^{2)}$ があり、 今後の保存政策が課題となっている。

筆者らは前報(文3,4,5) において歴史的遺産保存地区における当該 $\mathrm{P}$ S MV の現状と問題点を把握するために違反建築の調査、許可申請内 容の分析、違反者へのヒアリングなどを行った結果、(1)違反建物の指 摘件数は $\mathrm{ZPP}-\mathrm{Ua}$ 地区と $Z \mathrm{PP}-\mathrm{Ub}$ 地区がその大半を占めており、その建 築用途は大半が住宅用途であること、(2)違反建築物における許可申請 の状況は全体の約 $86 \%$ が申請を行っておらず、その割合は 2002 年に 対して 2003 年でやや增加していること、(3)設計や施工を行うのが建 築の専門家ではない住民自身であるために、政府が策定した P S MV の規則が十分に理解されていない可能性があることなどが明らかと なった。

\footnotetext{
*1 大阪大学大学院工学研究科建築工学専攻 博士後期課程 $\cdot$ 修士

*2 ARC 代表 工博

*3 大阪大学サイバーメディアセンター＼cjkstart教授・工博
}

ただ今後の効果的な保全活動を考える上で様々な課題が残されてい る。その中でも実際に保全活動をになう住民側の意識が重要であり、 P S MVの規制内容の理解や歴史的町並み保存の意義、積極的な住民 参加の意志などを把握する必要がある。

また、行政側に関しても申請の審査と許可が現在はまだユネスコの 主導で行われている状態であり、ラオス政府の歴史的町並み保存政策 への取り組みの現状と、行政担当者の認識を把握することが重要であ る。

これまでラオスにおける住民意識を扱った研究として、河本ら (文 6,7$)$ はラオスの中部の農山村住宅を取り上げ、住宅形態と住民意識を調査 し住宅建設の費用、便利さ、採光、通気性など住環境に関してはほぽ 満足であるのに対して、住宅寸法に関しては不満と感じていること、 将来の住居様式は高床式から 2 階建てに移行していくと考えられる ことなどを明らかにしている。しかしこれらは歴史的遺産保存地区に 関するものではない。

また内海ら (文8) はベトナムのホイアンにおける条例実施前後の状 況と住民の町並みへの意識を調查しており、条例に対する住民の反応

Graduate Student, Architectural Eng., Graduate School of Engineering, Osaka Univ., M. Eng.

ARC Organization, Dr. Eng.

Prof., Cybermedia Center, Osaka Univ., Dr. Eng. 
などを明らかにしている。

本稿ではラオス政府の保存政策に関する取り組みについてルアン プラバンと首都であるヴイェンチャンの行政担当者にヒアリングを 行うとともに、ルアンプラパンの住民やヴイェンチャンの学生などに 対して歴史的町並み保存に関する意識調查アンケートを行うことで、 今後の効果的な保存政策の検討のための手がかりを得ることを目的 としている。

\section{2. 方法}

\section{1 行政担当者へのヒアリンク}

\subsection{1 調查対象}

ヒアリング対象はヴィエンチャンとルアンプラバンの建築都市開 発部及び情報文化局と国立大学、都市開発調查局保存事務所（以下 IRU)、ユネスコ現地事務所である。表 1 にヒアリングを行った政府の 部門と担当者を示す。情報文化局は県全体の文化遺産物・生活文化の 保全を行う機関であり、IRU はウィエンチャン市の歴史的遺産保全地 区の調査、規制条例の策定を行う機関である。またラオス国立大学の 建築学部は現在ラオスで唯一の建築系の高等教育を行っている機関 であり、政府の行政担当者の多くがこの大学の卒業生である。彼らは いずれもラオスの開発、保存政策の第一線で活躍している人々で、現 在直面している課題を経験的に把握していると考えられる。

表 1.ヒアリング対象

\begin{tabular}{|l|l|l|l|}
\hline 部門 & 場所 & 役職 & 月 \\
\hline 国立大学建筑学部 & ウィエンチャン & 教頭 & 2004年11月4日 \\
\hline 市都市開発部 & ウィエンチャン & 蕃相.担当者 & 2004 年11月23日 \\
\hline 都市開発調査局保存事務所(IRU) & ウィエンチャン & 専門技術者 & 2004年11月5日 \\
\hline 県建築都市計画 & ルアンプラバン & 審查担当者 & 2004 年11月10日 \\
\hline 市都市開発部 & ルアンプラバン & マネージャ & 2004 年11月8日 \\
\hline 情報文化局 & ルアンプラバン & 課長 & 2004 年11月18日 \\
\hline ユネスコ現地事務所 & ルアンプラバン & 所長 & 2004 年11月17日 \\
\hline
\end{tabular}

\section{1 .2 調查内容}

ヒアリングの期間は 2004 年 11 月 4 日から 23 日で、筆者らが直接 面談して回答を得る。政府の各部門へのヒアリング内容は各部門の歴 史的町並み保存に対する業務内容及びこれまでに取り組んだプロジ エクト、広報の内容、それに関する問題点・課題、ルアンプラバンの P S M Vに対する意見などである。

表 2. 対象被験者

\begin{tabular}{|c|c|c|c|}
\hline $\begin{array}{l}\text { 被験者 } \\
\end{array}$ & 記号 & 合計 & 月日 \\
\hline ルアンプラバンの一般の住民 & LP-C & 38 & 2004年11月 12 日 \\
\hline ルアンプラバンの小学校 教師 & LP-T1 & 18 & 2004年11月 10 日 \\
\hline ルアンプラバンの中・高学校教師 & LP-T2 & 28 & 2004年11月 11 日 \\
\hline スパーヌヴォン大学の学生 & $L P-G$ & 53 & 2004年11月8日 \\
\hline ラオス国立大学·建築学科の学生 (構造コース) & VT-E & 30 & 2004年11月 5 日 \\
\hline ラオス国立大学·建築学科の学生 (建築コース) & VT-A & 30 & 2004年11月 4日 \\
\hline 合計 & & 197 & \\
\hline
\end{tabular}

\section{2 住民へのアンケート調査}

\subsection{1 調查対象}

表 2 に今回のアンケート調查の被験者を示す。被験者のグループは 6 つでヴィエンチャンにおいてはラオス国立大学建築学科の学生 60 名（建築コース 30 名、構造コース 30 名）、ルアンプラバンにおいて はスパーヌヴォン大学の学生 53 名、ルアンプラバンの小学校の教師
18 名、ルアンプラバンの中・高学校の教師 28 名、ルアンプラバンの 一般住民 38 名、合計 197 名である。

\subsection{2 調查内容}

調查期間は 2004 年 11 月 4 日〜 12 日で、アンケート調査票を配布し て回答を求めた。図 $1 、 2$ にアンケート調査票の一例を示す。質問内 容は 2 つの部分から構成され、I 部（図 1) は被験者の個人情報及び 建築行為の主体に関する設問とルアンプラバンの歴史的町並み保存 に関する意識調査である。II 部（図 2）は写真を用いたアンケートで ルアンプラバンのイメージを確認するものと被験者が希望する町並 みや住宅を確認するものから構成されている。写真の選択に関しては ルアンプラバンの保存地区内における特徵的な景観や町並み及び伝 統的住宅から最近の住宅までの代表的なものを選定した。

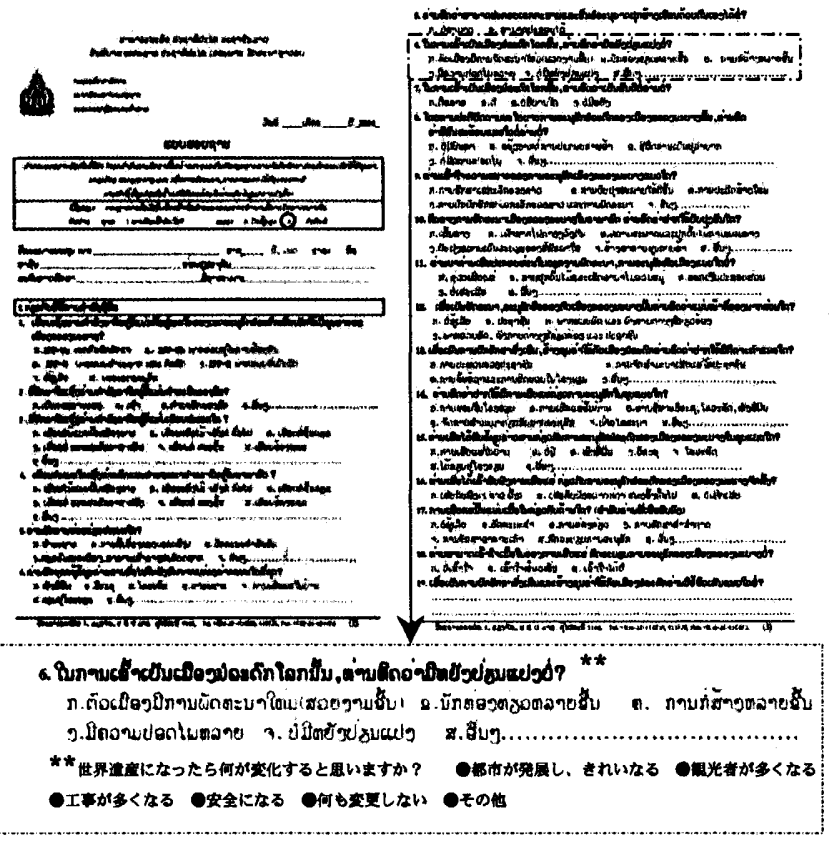

図 1.アンケートの一例（I 部）
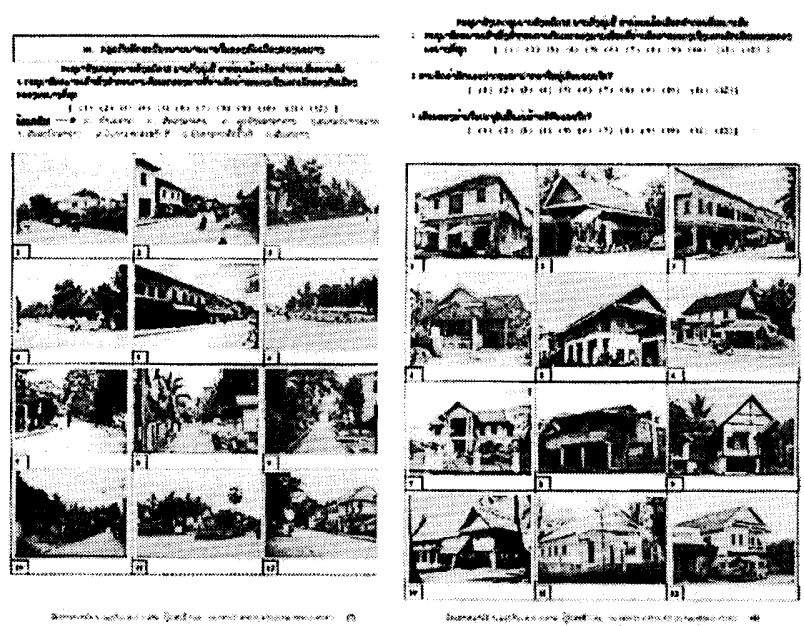

図 2. アンケートの一例（II 部）

\section{3.結果と考察}

3. 1 行政担当者ヘのヒアリング結果

表 3，4 に政府の各部門へのヒアリング結果を示す。これを見ると 
ラオスの歴史的町並み保存とルアンプラバンのP S MVに関して、住 民側の問題点は、彼らが規制通りすることに慣れておらず、建築図面

表 3. 政府の各部門へのヒアリング結果（ヴィエンチャン）

\begin{tabular}{|c|c|c|c|}
\hline 部門 & 国立大学建築学部 & 市都市開発部 & 開発調查局保存事務所 \\
\hline 場所 & ヴィエンチャ゙ & ヴィエンチャン & ヴィエンチャン \\
\hline 役職 & 数頭 & 䪤查担当者 & 専門技術者 \\
\hline 日時 & 2004年11月 4日 & 2004年11月 23日 & 2004年11月5日 \\
\hline \begin{tabular}{|l} 
歴史的遭産保存に閏し \\
て行っている業務内容
\end{tabular} & 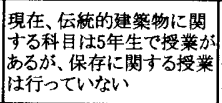 & 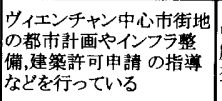 & $\begin{array}{l}\text { 光ィエンチチン市における } \\
\text { 歴史的遗産保全地区の調 } \\
\text { 查、規制条例の策定 }\end{array}$ \\
\hline 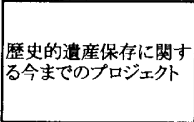 & 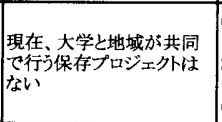 & 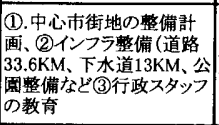 & $\begin{array}{l}1 \text { ナッサイ村、ドメン村の } \\
\text { 伝統的住宅の保全プロ } \\
\text { ジ施2.規制ガイドライン } \\
\text { の策定 }\end{array}$ \\
\hline 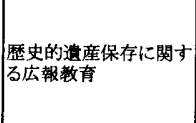 & 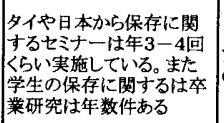 & 奉施段階ゼ & 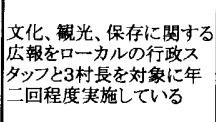 \\
\hline 上記の問題点·課題 & $\begin{array}{l}\text { ラスス人の建築家(専門 } \\
\text { 家)は保存のことにあまり } \\
\text { 詳しくない }\end{array}$ & & $\begin{array}{l}\text { 現地アンクート調查の実 } \\
\text { 績がそしく、調植票作成に } \\
\text { ついて困っているる }\end{array}$ \\
\hline |PSMVに対する意見 & $\begin{array}{l}\text { PSMVの規制内容は皦し } \\
\text { いといらのでななく、住民 } \\
\text { の生活に合っていないと } \\
\text { 考える。 }\end{array}$ & & 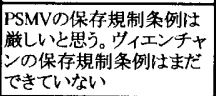 \\
\hline $\begin{array}{l}\text { 文化保存、生活保存に } \\
\text { ついて }\end{array}$ & 住民の生活文化は守りにく & & 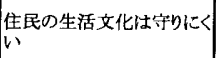 \\
\hline 他の保存すぺき場所 & $\begin{array}{l}\text { ラォス北部の少数民族の } \\
\text { 村やワットチャン地、タク } \\
\text { イ地区 }\end{array}$ & & 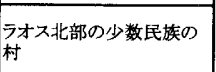 \\
\hline
\end{tabular}

表 4. 政府の各部門へのヒアリング結果（ルアンプラバン）

\begin{tabular}{|c|c|c|c|c|}
\hline 部門 & 県建箑都市計画 & 市都市開発部 & 情報文化局 & コネスコ事務所 \\
\hline 場所 & ルアンプラパン & ルアンプラバン & ルアンプラバン & ルアンプラバン \\
\hline 役職 & 審查担当者 & マネージャ & 課長 & 所長 \\
\hline 日時 & 2004年11月 10 日 & 2004年11月8日 & 2004 年11月 18 日 & 2004年11月 17日 \\
\hline $\begin{array}{l}\text { 歴史的遗産保存に閏し } \\
\text { て行っている業務内容 }\end{array}$ & $\begin{array}{l}\text { ルアンプラバン市保 } \\
\text { 存地区以外の建 } \\
\text { 許可申請と睢全体 } \\
\text { 都市計画を管理し } \\
\text { ている }\end{array}$ & 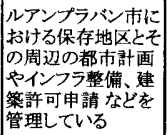 & 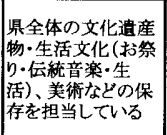 & $\begin{array}{l}\text { PSMVの指尊、住民 } \\
\text { 人の情報提供、保 } \\
\text { 存凟金の調達, }\end{array}$ \\
\hline 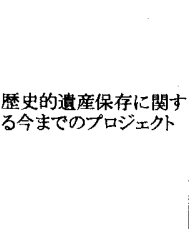 & 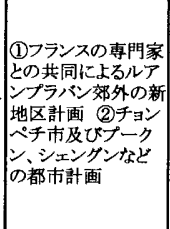 & $\begin{array}{l}1 \text { インフララ整備, } 2 \\
\text { マーケケットの建設, } 3 \\
\text { ヨミ処理 }\end{array}$ & 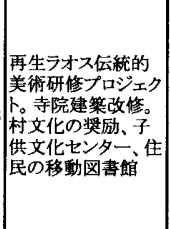 & 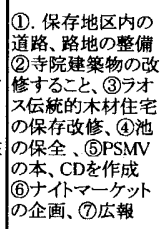 \\
\hline $\begin{array}{l}\text { 歴史的遗産保存以関す } \\
\text { る広報教育 }\end{array}$ & $\begin{array}{l}\text { ルアンプラバン市 } \\
\text { (58村)の村長を対 } \\
\text { 象に都市計画法及 } \\
\text { U建築基隻㚘制を } \\
\text { 年1回講義している }\end{array}$ & 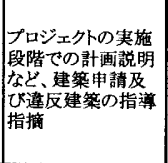 & 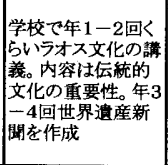 & 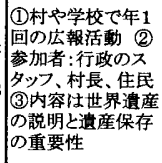 \\
\hline 上記の問題点·課題 & 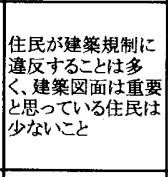 & 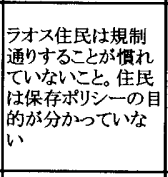 & $\mid$\begin{tabular}{|l} 
保存の活動は住民 \\
があまり参加しないい
\end{tabular} & 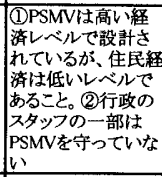 \\
\hline PSMVに対する意見 & 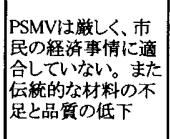 & 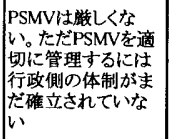 & $\begin{array}{l}\text { PSMVの內容は住 } \\
\text { 包には理解できな } \\
\text { | }\end{array}$ & $\begin{array}{l}\text { PSMVは族しくない } \\
\text { が、その現実 } \\
\text { 的でないいくつがの } \\
\text { 部分がある }\end{array}$ \\
\hline $\begin{array}{l}\text { 文化保存、生活保存に } \\
\text { ついて }\end{array}$ & 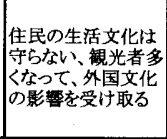 & 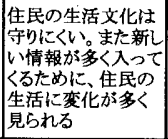 & $\begin{array}{l}\text { 住民の生活文化は } \\
\text { 守りにくい }\end{array}$ & $\begin{array}{l}\text { 集民の生活文化が } \\
\text { 守りにとくい }\end{array}$ \\
\hline 他の保存すべき場所 & $\mid \begin{array}{l}\text { ヴィエンジ+洞箄、自 } \\
\text { 然、パータンなと }\end{array}$ & $\begin{array}{l}\text { パークウー洞窑、や } \\
\text { 自然·森、など }\end{array}$ & $\begin{array}{l}\text { パークウー洞窟、や } \\
\text { 自然·森、など }\end{array}$ & $\begin{array}{l}\text { (1)ホーパン県の立 } \\
\text { 石、(2)森、自然 }\end{array}$ \\
\hline
\end{tabular}

を重要と思っている住民は少ないこと、また住民は歴史的町並み保存 の目的を理解しておらず、保存の活動に積極的でないこと、さらにP S MVが住民の生活や経済の現状に適合していないこと(注2) などが 指摘されている。

また行政能力上の問題として P S M Vを適切に管理するための体 制がまだ十分に確立されておらず、それを管理するスタッフを美成で きていないこと、またそのスタッフはラオス国立大学の出身者が多い が、ラオス国立大学では現在も伝統的建築物の保存に関する授業があ まり行われていないこと、さらに行政のスタッフの一部でも P S MV を守っていないという事実があることなどが指摘されている。これ らのコメントはラオスの保存政策を実施している行政側の認識であ る。

\section{2 住民へのアンケート結果}

\section{2 .1 被験者の属性}

表 5 に今回の調査対象の属性を示す。これによると男性は 105 名女 性は 92 名である。年齢構成はヴィエンチャンは大学生であるため 20 歳前後であり、ルアンプラバンは大学生以外に社会人も含まれている ため 10 歳〜 49 歳に分布している。

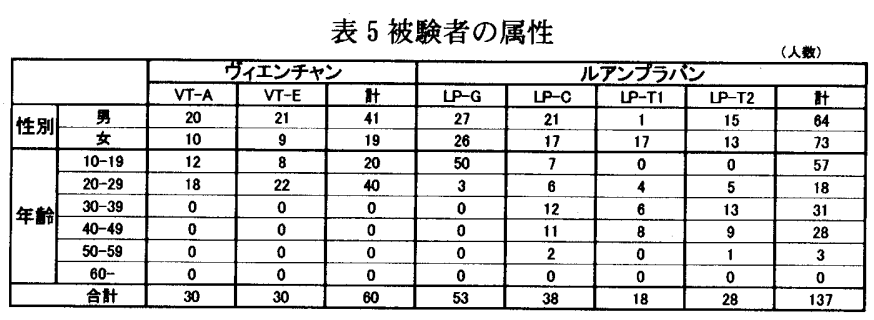

\subsection{2 歴史的町並み保存に関する住民意識}

表 6 に歴史的町並み保存に関する質問結果を示す。 表 6 歴史的町並み保存に関する質問

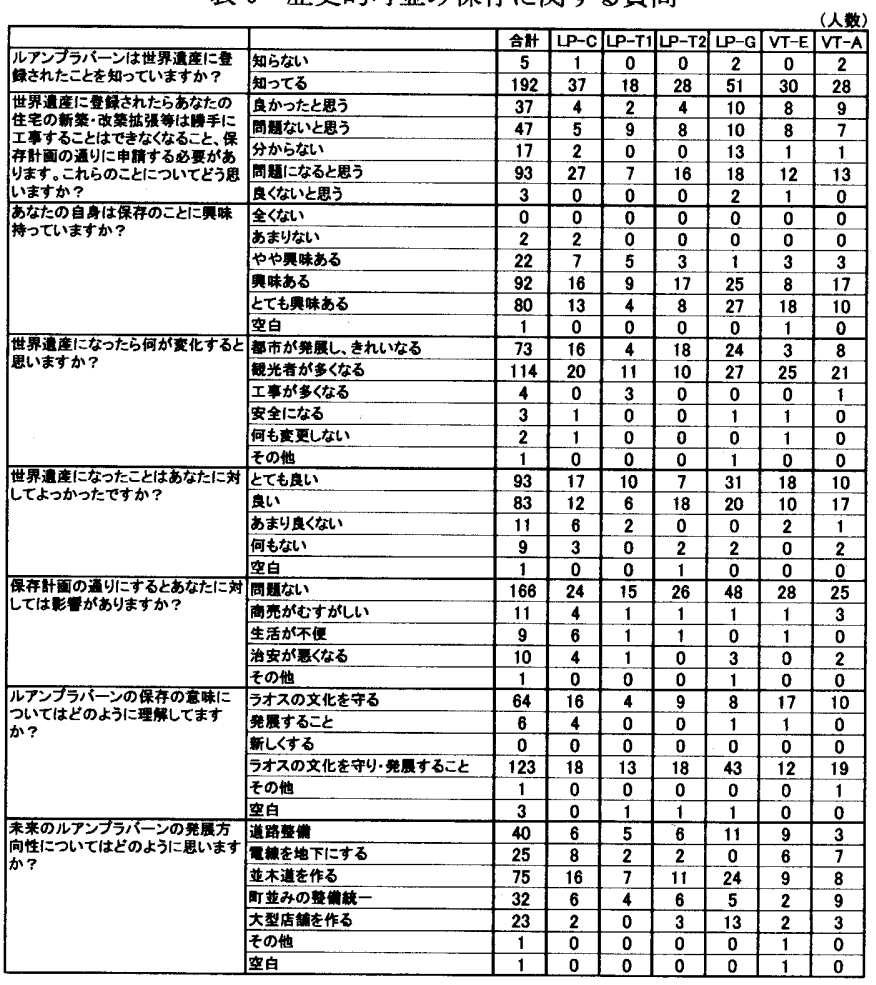

これによると大半の被験者はルアンプラバンが世界遺産に登録さ 
れたことを知っており、それによって観光客が多くなり、都市が発展 し、きれいになると考えている。また、ルアンプラバンの保存の意味 についてもラオスの発展と固有の文化を守るためと言う回答が多い ことから行政の広報が住民に行き渡っていると考えられる。一方、保 存政策によって住民自身の住宅工事が規制されることに対しては、問 題であると思う人が多く見られた。この結果はルアンプラバン、ヴィ エンチャンの各被験者に共通しており、日本での既往研究 (住3) とも 一致する。

表 7 に教育・広報に関する質問結果を示す。これによると $65 \%$ は歴 史的町並み保存に関する教育を受けており、そのうちルアンプラバン の住民のほうがヴィエンチャンよりも多いことが分かる。教育を受け た場所はルアンプランの住民や教師は村長からが多く、学生は学校で と回答している。ルアンプラバンの住民の教育回数は 1 回 2 回が最 も多い。また、教育内容に関しては全般的に文化に関するものが多い が、ルアンプラバンの住民では保存規制に関するものも多い。また住 民がどんな方法で教えてほしいかについてラジオ・テレビ・新聞など が最も多く、次にゼミナール（集会）、学校と回答している。

表 7 教育・広報に関する質問

\begin{tabular}{|c|c|c|c|c|c|c|c|c|}
\hline & & 合胡 & LP-C & $|P-T|$ & LP-T2 & $L P+G$ & VT-E & VT-A \\
\hline \multirow{8}{*}{ 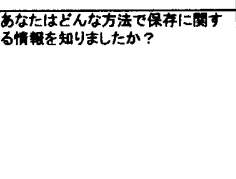 } & की & 35 & 15 & 8 & 6 & 4 & 2 & \\
\hline & tac & 10 & 3 & 0 & 2 & 0 & 2 & 3 \\
\hline & 然的 & 27 & 7 & 1 & 2 & 7 & 8 & 2 \\
\hline & 5シォ & 34 & 7 & 1 & 1 & 18 & 1 & 6 \\
\hline & TレLE & 53 & 2 & 5 & 13 & 8 & 14 & 11 \\
\hline & 業校飞 & 29 & 4 & 3 & 2 & 15 & 1 & 4 \\
\hline & \begin{tabular}{|l|} 
五の他 \\
\end{tabular} & 6 & 0 & 0 & 1 & 0 & 1 & 4 \\
\hline & 空白 & 3 & 0 & 0 & 1 & 1 & 1 & 0 \\
\hline \multirow{3}{*}{ 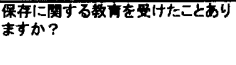 } & $\frac{150}{36}$ & 127 & 23 & 17 & 20 & 38 & 17 & 12 \\
\hline & $2 a$ & 68 & 15 & 1 & 8 & 14 & 12 & 18 \\
\hline & 空白 & 2 & 0 & 0 & 0 & 1 & 1 & 0 \\
\hline \multirow{5}{*}{ 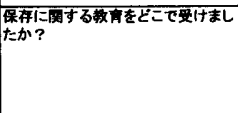 } & 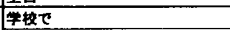 & 51 & 4 & 3 & 5 & 28 & 8 & 3 \\
\hline & 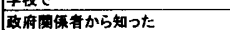 & $\frac{31}{39}$ & $\frac{4}{9}$ & $\frac{3}{6}$ & 5 & $\frac{20}{7}$ & $\frac{0}{4}$ & $\frac{5}{8}$ \\
\hline & 和垤方 & 33 & 10 & 8 & 9 & 3 & 3 & 0 \\
\hline & その他 & 4 & 0 & 0 & $i$ & 0 & 2 & 1 \\
\hline & 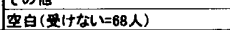 & 2 & 0 & 0 & 0 & 1 & 1 & 0 \\
\hline \multirow{3}{*}{ 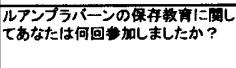 } & 1回 2回 & 73 & 16 & 11 & 14 & 13 & 12 & $\frac{7}{7}$ \\
\hline & 2回以上 & 45 & 7 & 6 & 6 & 18 & 5 & 3 \\
\hline & 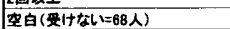 & 11 & 0 & 0 & 0 & 8 & 1 & 2 \\
\hline \multirow[t]{7}{*}{ ビんな内察でしたか？ } & 分からない & 19 & $\frac{2}{2}$ & 0 & 4 & 10 & 1 & 2 \\
\hline & 文化 & 40 & 5 & 10 & 5 & 9 & 6 & 5 \\
\hline & 會光 & 15 & 0 & 2 & 1 & 3 & 7 & 2 \\
\hline & 自裙保存 & 14 & 2 & 4 & 2 & 6 & 0 & 0 \\
\hline & 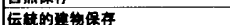 & 16 & 2 & 1 & 3 & 6 & 1 & 3 \\
\hline & 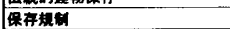 & 23 & 12 & 0 & 5 & 4 & 2 & 0 \\
\hline & 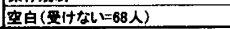 & 2 & 0 & 0 & 0 & 1 & 1 & 0 \\
\hline \multirow{4}{*}{ 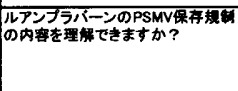 } & 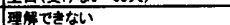 & 15 & 2 & 0 & $\frac{5}{1}$ & 4 & 3 & 5 \\
\hline & 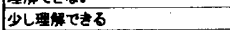 & 74 & 11 & 8 & 13 & 24 & 11 & 7 \\
\hline & 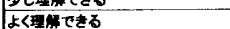 & 38 & 10 & $\frac{0}{9}$ & 6 & 10 & 3 & 0 \\
\hline & 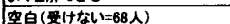 & 2 & 0 & 0 & 0 & 1 & 1 & 0 \\
\hline \multirow{7}{*}{ 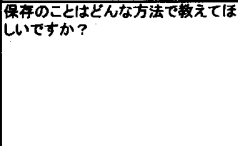 } & 杽校 & 34 & $\frac{10}{10}$ & 8 & 2 & 7 & 4 & 5 \\
\hline & 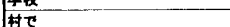 & 25 & $\frac{7}{7}$ & 1 & 5 & 4 & 3 & 5 \\
\hline & ラジオ・テレビ·㫀成 & 83 & 10 & 8 & 13 & 29 & 10 & 13 \\
\hline & 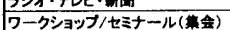 & 38 & $\frac{10}{9}$ & $\frac{8}{3}$ & $\frac{13}{5}$ & $\frac{29}{8}$ & $\frac{10}{8}$ & $\frac{10}{5}$ \\
\hline & 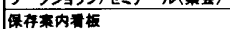 & 14 & $\frac{5}{2}$ & 0 & $\frac{5}{2}$ & 5 & 3 & $\frac{5}{2}$ \\
\hline & 一の地 & 1 & 0 & 0 & 0 & 0 & 1 & 0 \\
\hline & 案自 & 2 & 0 & 0 & 1 & 0 & 1 & 0 \\
\hline
\end{tabular}

表 8 住民参加に関する質問

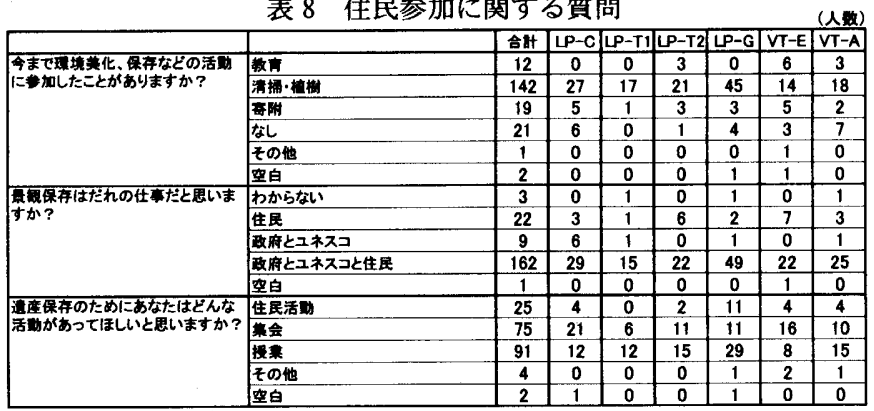

表 8 に住民参加に関する質問結果を示す。これによると「環境美化、 保存などの活動に参加したことがありますか」と言う質問に対して $90 \%$ はると回答しており、ルアンプラバンの景観保存と都市開発に ついても政府・ユネスコだけの仕事ではなく、住民も参加する必要が
あると認識していることが分かる。この結果はルアンプラバン、ヴィ エンチャンの各被験者に共通しており、ラオスの住民が協働活動に前 向きであることを示唆している。また、このことは行政担当者の認識 と異なっている。

\subsection{3 居住者イメージ調査}

アンケートの後半の設問はルアンプラバン市内の写真 12 枚から最 も質問内容にふさわしいと思う一枚を選択させ、その理由をマークさ せることで実施したものである。

(1)景観について

ルアンプラバンの景観を示す写真 12 枚に対して「ルアンプラバン らしい景観はどれか」と言う質問とその理由を尋ね、その結果を表 9 に示す。ルアンプラバンの景観に関して、全体では 5 番（王宮）が最 も多く、次に 3 番（プーシー山）となっているが、ヴィエンチャンの 被験者では 3 番が少なくなっている。このことはその選択理由からル アンプラバンの住民にとってはプーシー山がその象徴となっている 一方、ウィエンチャンの学生にとってはそれが意識されていないこと がわかる。

(2)町並みについて

ルアンプラバンの町並みを示す写真 12 枚に対して「ルアンプラバ ンらしい町並みはどれか」と言う質問とその理由を尋ね、その結果を 表 10 に示す。ルアンプラバンの町並み（表 10）に関して、ルアンプ ラバンの住民では 4 番（シェントン寺院近くの町並み）が最も多く、 次いで 3 番、11 番（ヴィエズン寺院前の町並み）、 5 番（プーシー山 前のメインストリート）の順で、ヴィエンチャンの学生とルアンプラ バンの住民では大きい差は見られない。その選択理由を見ると建物、 静寂となっており、ルアンプラバンの独自性を示す手がかりが伺える。 (3)住宅について

次にルアンプラバンにある住宅の写真 12 枚に関して「ルアンプラ バンらしい住宅」「自分が住んでみたい住宅」「現在自分が住んでいる 住宅に似ているもの」を選択させ、その結果を表 11 に示す。

これによると「ルアンプラバンらしい住宅」でもっとも多いのは 2 番、 4 番で、ヴィエンチャンの学生でもほほ 2 番、4 番が多い。2 番は ユネスコが改修した高床式の伝統的住宅であり、4 番はトンチャルン 村の住宅で、この建築物の様式はフランス植民地時代に多く見られる ものである。これらのことから保存すべき住宅イメージの共有はほぼ できていると考えられる。次に、「住んで見たい住宅」としては 7 番 の写真が最も多く、ヴィチャンの学生では 9 番が最も多い。前者は近 年多く見られる輸入材料を用いた洋風建築であり、伝統的な住宅では ないが、多くのラオス人に好まれていることがわかる。後者はラオス の植民地時代に建てられた伝統的な高床式の住宅で、建築学校の学生 にとってはラオスの伝統様式に対する理解が示されていると考えら れる。以上のことから、少なくとも「ルアンプラバンらしい住宅」と 「住みたい住宅」は異なっていることがわかる。また、「現在住んで いる住宅はどの写真に近いか」と言う質問に対して 8 番と 11 番が最 も多く、次に多いのは 12 番、 5 番の順である。このことはルアンプラ バンの住民、ヴィエンチャンの学生に共通している。8 番は伝統的で ない高床式の住宅、11 番は棟瓦造の住宅で一般に庶民が自分で建設す る場合が多いものであるが、2 番のようなラオスの伝統的な住宅とは 異なる。また 12 番は最近建てられた店舖付住宅で、 5 番は植民地時代 


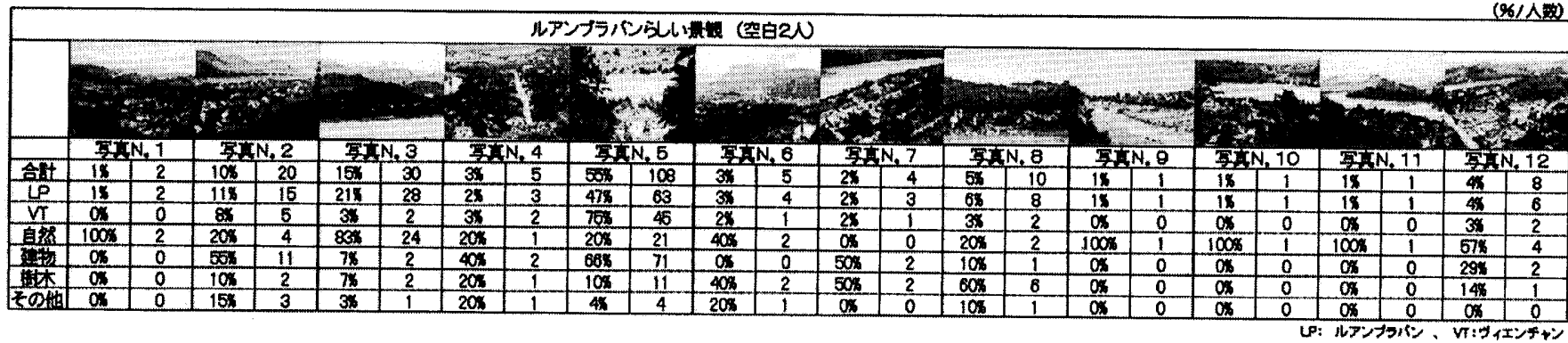

表 10 ルアンプラバン内の町並み

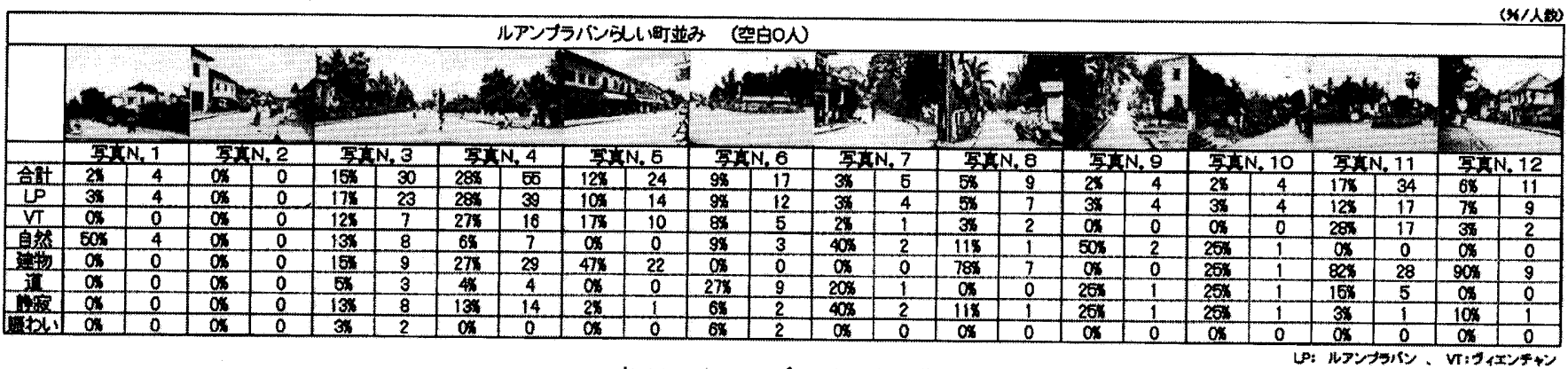

表11 ルアンブラバン内の住宅

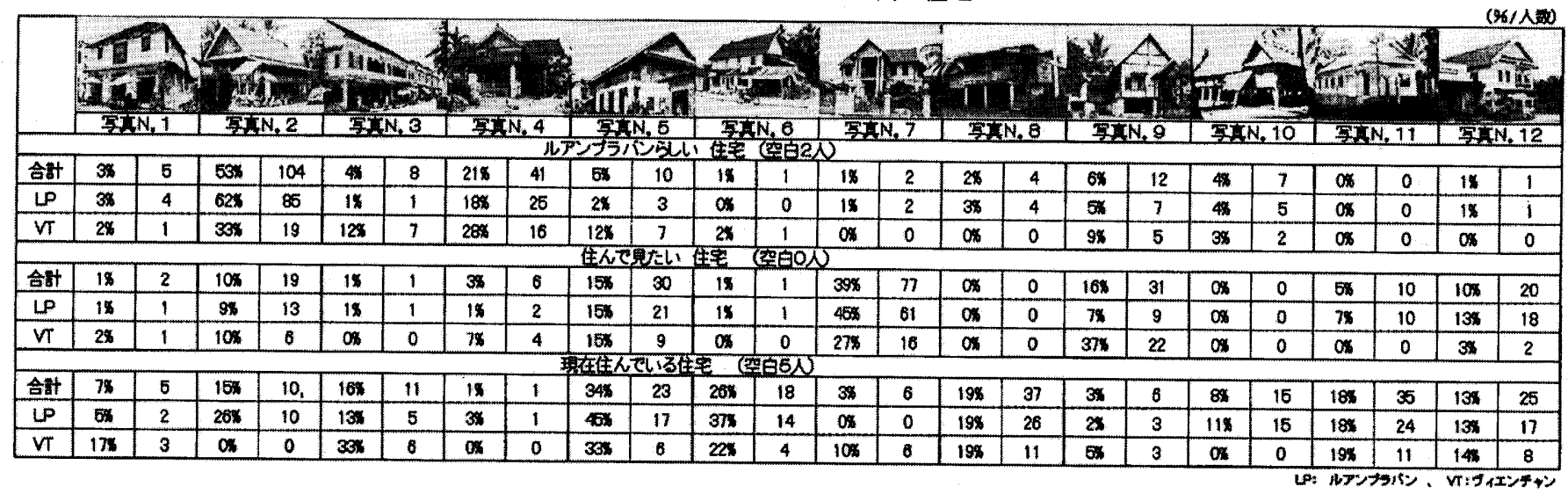

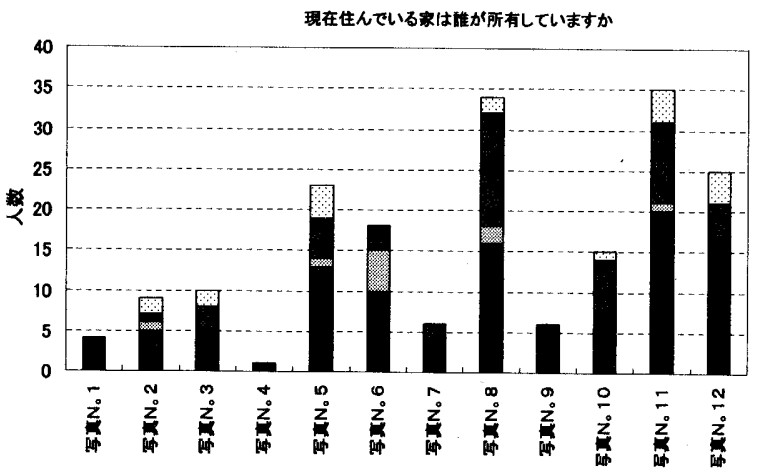

図 3 住んでいる家のタイプごとの所有形態

の様式を取り入れたものである。

次に図 3 に現在住んでいる家のタイプことの所有形態を示す。これ を見ると 8 番と 11 番の住宅は政府の所有の割合が高く、それ以外で は自己所有が多いことが分かる。また、6 番の住宅は賃貸の割合も多 く、これは伝統的な町並みに面している店舗付住宅で、観光客のため の店を経営していると考えられる。次に図 4 に前節で取りあけた遭産 保存に関する質問のうち住宅工事のための規制に関する意識を住ん

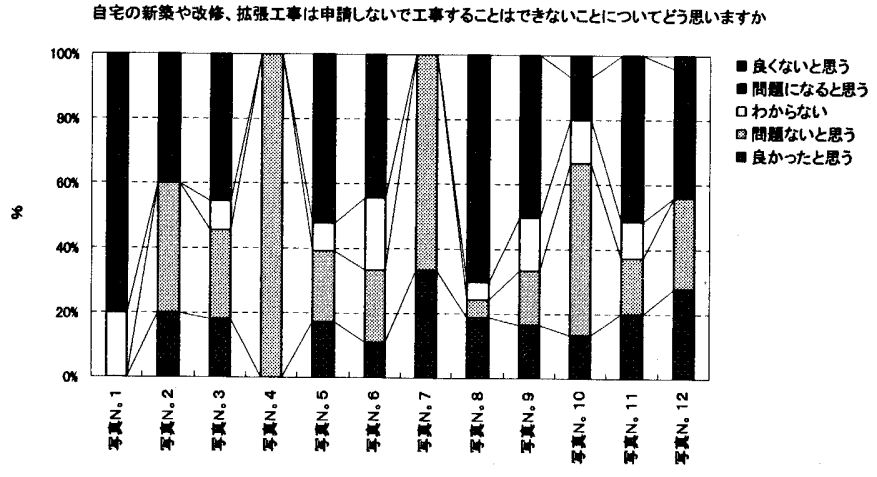

図4 住んでいる家のタイプごとの住宅規制に関する意識

でいる家のタイプごとに示す。これを見ると 1 番と 8 番は特に規制に 関して問題があると考えており、 4 番、7番、10 番はあまり問題がな いと考えている。前者において、8 番は伝統的でない高床式の住宅で あり、河本らの研究 (文6.7) を見ても一階部分を改修するケースが多く 見られ、今後改修工事に関する規制がきびしくなると困ることから 「問題である」と回答したと思われる。一方、後者において、10 番は ラオスの伝統的な高床式住宅であり、すでに保存指定されているか、 
または一階の部分の階高が低いために改修工事をあきらめているこ とから問題はないと回答した可能性がある。

\section{4. 結論}

本稿では行政政府の保存政策に関する考え方をルアンプラバン及 びヴイェンチャンの行政担当者にヒアリングを行うとともに、ルアン プラバンの住民や学生に対して歴史的町並み保存に関する意識調査 アンケートを行うことで、以下の結果を得た。

1 . 政府の担当者は住民が歴史的町並み保存の目的を理解しておら ず、保存の活動に積極的でないと認識しており、P S MVが住 民の生活や経済の現状に適合していないと認識している。

2. 大半の住民はルアンプラバンが世界遺産に登録されたことを知 っており、それによって観光客が多くなり、都市が発展し、き れいになると考えている人が多いが、保存政策によって住民自 身の住宅工事が規制されることに対しては問題であると思う人 が多く見られた。

3. 環境美化、保存などの活動に約 $90 \%$ の人は参加したことがある と回答しており、ルアンプラバンの景観保存と都市開発につい ても政府・ユネスコだけの仕事ではなく、住民も参加する必要 があると認識している。

4. 住民がルアンプラバンらしいと思っている住宅の調査から保存 すべき住宅イメージの共有はできていることを示唆する結果が 得られた。

5. 現在多くの住民が住んでいる住宅は高床式の住宅や棟瓦造の住 宅で、「現在住んでいる住宅」と「ルアンプラバンらしい住宅」 と「住みたい住宅」は異なっている。

6. 伝統的でない高床式の住宅に住んでいる人の多くは今後改修工 事に対する規制がきびしくなることには問題である意識してい る一方、ラオスの伝統的な高床式住宅に住んでいる人の多くは、 ・すでに保存指定されているか、または一階の部分の階高が低い ために改修工事をあきらめているなどから規制がきびしくなる ことには問題ないと意識している。

以上、行政側と住民側の歴史的町並み保存に関する意識を分析する ことで、住民側は保存の意義をある程度理解している一方、そのため に必要となる建築規制については十分認識できていない可能性があ る。また住民は積極的な保存活動に対する参加の意思を持っている一 方、行政側にはそれを効果的に生かし得る住民参加型の施策が整備で きていないこと、さらにその活動を支えていく経済的な支援システム の構築などが今後必要であると考えられる注4)。

\section{謝辞}

本稿の調査においてはユネスコ現地遺産事務所の Ouane SIRISACK 氏、Yushi KAWAGUCHI 氏、Savuer 氏、ラオス国立大学の Manorot Phini th 氏, Vira ANOLAC 氏、県文化事務所の Bounkong Kout thao 氏, 市都市開 発事務所の Chan tharangsy 氏、Daovanh 氏、県都市計画部 Somki th 氏、 VT 保存事務所の Vongs ack MALIVANH 氏に多大な協力をいただきました ことに謝意を表します。
注

注 1) PSMV (Plan de Sauvegarde et de Mise en Valeur/保全及び価値の維持 に関する計画規則) は歴史的遺産保存地区 (Zone de Protection du Patrimoine)を指定し、その地区内の開発行為や建築行為の規制を定めた ものである。PSMV はラオス政府の県建築管理委員会とUNESCO ラオス現 地事務所の共同によって策定が進められ、2001 年 4 月に正式な法律とし て施行された。

注 $2 ） 1998$ 年と 2003 年にユネスコが PSMV の規制通りにラオス伝統的住宅を改 修した工事金額は約 28000 US \$と 33000 US \$ (文9,10) であり、一方ラオス 人の住民一人あたりの平均年収は 360 US\$ (文11) であり、ラオス住民の経 済レベルとかけ離れている。

注 3）和田ら(文 ${ }^{12)}$ は日本の金沢市の伝統的建造物保存地区を対象にアンケート 調査実施し、地区指定により、観光客が增元街並みが良くなるものの、 規制強化に対する住民の不満や高齡化など将来に対する㬎念が解消され ていないことなどを明らかにしている。

注 4）筆者らは 2004.1.28-2.4 にラオス国立大学及びルアンプラバン県情報文 化局と共同で当該地区にある村のリーダーを集めて、CG アニメーション を用いて伝統的町並み保存のためのワークショップを開催した結果、参 加者からはCGアニメーションや写真などを用いた説明内容について「理 解しやすい」「よく理解できた」という意見が多く、ルアンプラバンの保 存規制に対しても「有用である」との回答を得た。

\section{参考文献}

文1) La Maison du Patrimoine "REgLeMENT、Ville du patrimoine mondial de L' UNESC0、Plan de sauvegarde et mise en valeur, Luang Prabang ". 2001.4

文 2) CONVENTION CONCERNING THE PROTECTION OF THE WORLD CUL TURAL AND NATURAL HERITAGE 30th Anniversary(1972-2002) WORLD HERITAGE COMMITTEE Twenty-sixth session Budapest, Hungary, 2002.6. 24-29 State of conservation of properties inscribed on the World Heritage list

文 3）SITTHIVAN SOMCHITH, 河本順子, 阿部浩和、吉田勝行 “ラオス・ルアンプ ラバーン市歴史的遺産保存地域における保存の規制と違反建物に関する 研究” 日本建築学会, 2003 年度大会（東海）学術講演梗概集, pp. $145-$ $146,2003,9$

文4）SITTHIVAN SOMCHITH，河本 順子，阿部 浩和 “ルアンプラパンの歴史 的遺産保存地区における PSWV の現状と課題”日本建築学会近幾支部研究 報告集，第 44 号・計画系，pp. $821-824,2004 、 6$

文5）SITTHIVAN SOMCHITH，河本 順子，阿部 浩和 “ルアンプラパンの歴史 的遺産保存地区における PSMV の現状と橦題”，日本建築学会計画系論 文集, 119-124, 2005 年 5 月

文6）河本順子, SITTHIVAN SOMCHITH, 吉田勝行, “ラオス中部における農山村 住宅の形態と住宅に関する住民意識”，日本建筑学会, 2003 年度大会 (東 海) 学術講演梗概集, pp. 515-516,2003,9

文 7）河本順子, SITTHIVAN SOMCHITH, 吉田勝行, “ラオス中部における農山村 住宅の形態変遉”，日本建築学会計画系論文集，Mar. 2004.

文 8）内海佐和子他 3 名、観光化に伴亏町並み変容と条例によるコントルール。 ヴェトナム・ホイアンの町並み保存に関する研究 その1 日本建築学 会計画系論文集 第 525 号、105-111、1999.11

文9) Culture Heritage Management And Tourism: Models for Co-operation among Stakeholders, A Case Study on Luang Prabang Lao PDR, 2000.4

文10) La Maison du Patrimoine, Premiere Phase Du Pass-LP, Lot No. 08, intitule" Restauration de Batimentl" :Tranche No.01, intitulee" RST-26” 2003.

文11) The World Bank Group Data and statistics Total GDP 2003 $\mathrm{ht}$ tp://www. wor ldbank. org/data/da taby topic/GDP. pdf

文12）和田章仁, 益岡了, “町並み保全に関する地域住民の意識変化”, 日本 建築学会, 2003 年度大会 (東海) 学術講演梗概集, pp. $231-232,2003,9$ 